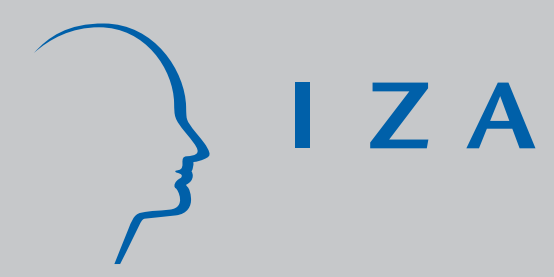

IZA DP No. 1390

Religion as a Determinant of Economic and Demographic Behavior in the United States

Evelyn L. Lehrer

November 2004 


\title{
Religion as a Determinant of Economic and Demographic Behavior in the United States
}

\author{
Evelyn L. Lehrer \\ University of Illinois at Chicago \\ and IZA Bonn
}

\section{Discussion Paper No. 1390 \\ November 2004}

\author{
IZA \\ P.O. Box 7240 \\ 53072 Bonn \\ Germany \\ Phone: +49-228-3894-0 \\ Fax: +49-228-3894-180 \\ Email: iza@iza.org
}

\begin{abstract}
Any opinions expressed here are those of the author(s) and not those of the institute. Research disseminated by IZA may include views on policy, but the institute itself takes no institutional policy positions.
\end{abstract}

The Institute for the Study of Labor (IZA) in Bonn is a local and virtual international research center and a place of communication between science, politics and business. IZA is an independent nonprofit company supported by Deutsche Post World Net. The center is associated with the University of Bonn and offers a stimulating research environment through its research networks, research support, and visitors and doctoral programs. IZA engages in (i) original and internationally competitive research in all fields of labor economics, (ii) development of policy concepts, and (iii) dissemination of research results and concepts to the interested public.

IZA Discussion Papers often represent preliminary work and are circulated to encourage discussion. Citation of such a paper should account for its provisional character. A revised version may be available directly from the author. 


\section{ABSTRACT \\ Religion as a Determinant of Economic and Demographic Behavior in the United States*}

This paper critically reviews and synthesizes research on the role of religion on various aspects of the economic and demographic behavior of individuals and families in the United States, including the choice of marital partner, union formation and dissolution, fertility, female time allocation, education, wages, and wealth. Using a theoretical framework based on Gary Becker's contributions to the economics of the family, religious affiliation is seen to affect these outcomes because it has an impact on the costs and benefits of many interrelated decisions that people make over the life cycle. In addition, for behaviors that pertain to married couple households, affiliation matters because it is a complementary trait within the context of marriage. Religiosity, another dimension of religion, also affects economic and demographic outcomes, partly because it accentuates differences by religious affiliation, partly because of the generally beneficial effects that religious involvement has on health and well-being.

JEL Classification: J1, J2

Keywords: religion, demography, marriage, female employment, education, fertility

Evelyn L. Lehrer

Economics Department

University of Illinois at Chicago

601 South Morgan Street

Chicago, Illinois 60607-7121

USA

Email: elehrer@uic.edu

\footnotetext{
* Earlier versions of this paper were presented at the 2002 meetings of the Society for the Scientific Study of Religion at a session honoring Gary Becker and his contributions to the Economics of Religion; at the seminar series of the Waterhead Center for International Affairs, Harvard University; and at Economics Department workshops at George Mason University and the University of Illinois at Chicago. I am indebted to participants at these seminars, Barry Chiswick, and three anonymous referees for many helpful suggestions and comments.
} 


\section{Religion as a Determinant of Economic and Demographic Behavior in the United States}

A large body of literature documents that religion has important effects on various aspects of the economic and demographic behavior of individuals and families in the United States, including the choice of marital partner, entry into cohabitation and marriage, divorce, fertility, women's work at home and in the market, education, wages, and wealth. Until now, these various relationships have been studied one at a time, in isolation. Using an analytical framework based on Becker's theory of the economics of the family (1981), this paper critically reviews and synthesizes the theoretical and empirical research to date, and identifies pathways through which religion has an impact; gaps in our knowledge are noted.

The main focus of this study is on religious affiliation (the specific religious group to which the individual belongs) as a determinant of economic and demographic outcomes. It is argued below that religious affiliation matters because it has an impact on the perceived costs and the perceived benefits of various interrelated decisions that people make over the life cycle. In addition, for behaviors that pertain to married-couple households, as opposed to individuals, religion matters because it is a complementary trait within marriage, affecting many activities that husband and wife engage in together.

Religiosity encompasses such dimensions as commitment to the religion, the strength of religious beliefs, and participation in religious activities individually or as part of a congregation. This paper develops the argument that religiosity has an impact on economic and demographic outcomes partly because it accentuates the effects of 
affiliation, partly because its generally positive influence on health and well-being can have repercussions for such outcomes.

The sections that follow review the role of religion in each of the economic and demographic outcomes cited above.

\section{Marital Stability}

In a path-breaking paper, Gary Becker (1973) developed the economic theory of marriage. One of the many useful insights in this study is that in the optimal sorting in the marriage market, there is negative assortative mating for traits that are substitutes and positive assortative mating for traits that are complementary. This idea has played a key role in all subsequent economic analyses of the effects of religion in the behavior of married couples. Religion is a complementary trait within marriage, because it affects a large number of activities in which both spouses are involved, as a couple, beyond the purely religious sphere. These include the education and upbringing of the children, the allocation of time and money, the cultivation of social relationships, and often even the place of residence. As a result, there is greater efficiency in a household if husband and wife share the same religious beliefs. The other side of this argument is that a difference in religion between the partners would be a destabilizing force within a marriage. Several studies provide support for the hypothesis that the probability of divorce is higher for religiously heterogamous couples (Bumpass and Sweet 1972; Becker et al. 1977; Michael 1979; Lehrer 1996c).

Not all religious intermarriages are the same, however: they come in different forms and shades. Analyses based on data from the 1987-88 National Survey of Families 
and Households (NSFH) reveal that the most unstable intermarriages include those in which (a) the beliefs of the two religious groups are very different (e.g., an inter-faith union involving a Jew); (b) one or both of the partners are affiliated with a religion that has sharply defined boundaries and has sought more separation from the broader culture (e.g., an inter-faith union involving a conservative Protestant); or (c) one of the partners has no affiliation. The magnitude of the religious intermarriage effect is large. For a homogamous mainline Protestant couple with typical characteristics, the probability of marriage dissolution within five years is 0.20 . The corresponding probability for interfaith unions ranges from a low of 0.24 for those that are most stable to a high of 0.42 for the least stable (Lehrer and C. Chiswick 1993).

Among Catholics and Protestants in the U.S., unions that achieve homogamy through conversion are at least as stable as those involving partners who were brought up in the same religion (Lehrer and C. Chiswick 1993). When an individual switches to another faith to achieve religious homogamy, this usually follows a process involving study of the new religion, and converts are often even more observant than those who grew up in the faith. The process of conversion appears to put husband and wife on the same page, eliminating any destabilizing influences associated with having grown up in different religious traditions. Whether conversion has a similar effect also for other groups, such as Jews and Mormons, is not known at present.

Beyond the heterogamy vs. homogamy distinction, religion affects marital stability because the faith to which an individual belongs has an impact on the perceived costs of marital dissolution. Since virtually all religions are pro-family, affiliation with any faith should have a stabilizing influence, although the effect may be more 
pronounced in some cases than in others. Indeed, analyses of data from the 1987-88 NSFH reveal that by far, the most unstable homogamous unions are those involving two unaffiliated partners: such unions have a fifth-year dissolution probability of fully 0.36 , compared to 0.20 for homogamous mainline Protestant unions. At the other extreme, homogamous Mormon marriages stand out for their high level of stability, with a probability of 0.13 (Lehrer and C. Chiswick 1993). In the past, Catholic unions had been unusually stable, a result attributed to the Catholic Church's prohibition against divorce (Michael 1979), but more recent analyses do not find a Catholic differential in this regard (Lehrer and C. Chiswick 1993).

Virtually nothing is known about the implications of religious heterogamy for children. Inter-faith couples face three, very different choices: to raise their children with no religion; to raise them in the faith of one of the parents; or to involve them to some degree in both religions. The first path may deprive children of the various benefits that are associated with some religious involvement during childhood and adolescence (Smith 2003; Waite and Lehrer 2003). While the other two paths do provide such involvement, the implications for the children of possibly receiving conflicting messages, or of sharing religious activities with only one parent, have not been studied in a systematic way.

\section{The Choice of Marital Partner}

The section above noted that marrying outside the religion is generally destabilizing, and the effect is sometimes quite large. An interesting question, therefore, is: why is it that so many people go ahead and choose a partner of a different faith, often without a conversion? The first scholar to address this question in the economics literature was, 
again, Gary Becker (1981), who outlined various factors that would tend to make intermarriage more likely for a particular individual. His emphasis was on negative factors (p. 232):

The most plausible explanation is that persons enter mixed marriages even though they anticipate a higher probability of divorce because they do not expect to do better by further search and waiting. Perhaps they were unlucky in their search and became pregnant, or have aged and fear a diminishing market... Some persons enter mixed marriages not because they are unlucky but because they are inefficient at discovering suitable prospects or have other characteristics that lower their expected gains from marriage.

An extension of Becker's analysis considers a broader set of factors that influence the probability of entering an inter-faith union (C. Chiswick and Lehrer 1991). The point of departure in this model is that religion is only one of many traits that are important in the marriage market, and there are tradeoffs. Individuals face benefits from continued search for a same-faith partner and also costs; the optimal level of religious compatibility is that which equates the benefits and costs at the margin. This model predicts that a key determinant of the likelihood of intermarriage is the individual's commitment to the religion in which he or she was raised (which affects the benefits of continuing to search for a same-faith partner). Another is the nature of the local marriage market, i.e., how difficult it is to find a coreligionist (which affects the costs of continuing to search for a same-faith partner). Subsequent empirical work has shown that indeed those two factors are important determinants of intermarriage (Lehrer 1998). In more recent research, Sherkat (2004) discusses the role of religious affiliation per se on the likelihood of placing an emphasis on religion when choosing a marital partner; he notes that intermarriage should be less common among people raised in those traditions that claim 
exclusive access to supernatural rewards and those that impose high costs on members for marrying outside the faith.

With regard to other factors, the effect of educational attainment on the probability of marrying outside the religion is ambiguous a priori. Highly educated individuals generate marriage offers more easily and thus have lower search costs; this effect predicts a lower probability of intermarriage. At the same time, a higher level of schooling implies wider intellectual horizons and additional dimensions of compatibility that may be traded off against compatibility in the religious sphere, implying a higher likelihood of intermarriage. Empirically, findings by Sherkat (2004) based on data from the 1973-1994 General Social Surveys suggest that education is positively associated with the probability of intermarriage. Analyses conducted separately for Catholics, mainline Protestants, and conservative Protestants, using data from the 1987-88 NSFH, also reveal a positive association, but only for the latter (Lehrer 1998). Among the most highly educated conservative Protestants, higher levels of intellectual achievement and socioeconomic status (which may more easily be found by widening the search to include possible partners outside the religion) appear to represent an important aspect of compatibility that is traded off against religious compatibility.

Geographic mobility is another factor that affects the probability of religious intermarriage. Sherkat (2004) notes that migration increases the likelihood of marrying outside one's faith, because it provides opportunities to meet people of different backgrounds and also disrupts social ties that constrain the choice of marital partner. At the same time, there may be endogeneity in the migration decisions: those who place a lower priority on religious homogamy may be more inclined to move. 
The past several decades have witnessed an increase in the rate of intermarriage for mainline Protestants, Catholics, and Jews (C. Chiswick 1997; Lehrer 1998; Sherkat 2004). In contrast, the rate has remained remarkably stable for conservative Protestants (Lehrer 1998; Sherkat 2004). This pattern suggests a greater resistance over time to secularization among the stricter denominations, a behavior that may account in part for their continued strength (Iannacconne 1994).

\section{Fertility}

Some religions provide psychic and social rewards to those who have many children, in the form of approval, social status, and blessings. As Stark and Finke (2000) have noted, the high fertility that Mormons have consistently displayed in the United States (Thornton 1979; Heaton 1986; Lehrer 1996a) can be interpreted as a rational response to such incentives. Similarly, the Catholic religion embodies strong pro-natalist ideologies, which raise the perceived benefits of having an additional child. It also has teachings that forbid artificial forms of contraception, oppose abortion, and increase the costs of family planning (Sander 1995). Until the 1970s, these norms had been manifested in a distinctive pattern of very high fertility. More recently, adherence to the teachings of the Catholic Church in these areas has weakened markedly, with a corresponding decline in family size (Jones and Westoff 1979; Mosher et al. 1986; Goldscheider and Mosher 1991). ${ }^{1}$ Some aspects of conservative Protestant ideologies are also pronatalist, and the fertility of this group has been found to exceed that of mainline Protestants, but only by a small margin (Marcum 1981; Lehrer 1996a).

At the other end of the continuum, Jews have consistently displayed unusually low fertility (Della Pergolla 1980; Mosher and Hendershot 1984). In this case, there are 
no doctrines in the religion per se that encourage a small family size, so explanations must be sought in other aspects of Judaism, the Jewish community, and its interactions with the broader society (Goldscheider 1971). It has been suggested in the economics literature that historically, Jews have faced a higher price of having an extra child (the reasons include higher rates of urbanization and female literacy) and may have therefore chosen to substitute expenditures per child ("quality") for quantity (Becker 1981; B. Chiswick 1988). In addition, as elaborated later in this paper, Jewish women attain very high levels of schooling. The persistently low fertility in the Jewish community today is intimately related to such attainment (Hurst and Mott 2003).

Virtually all that we know about differences by religion in fertility is based on studies that use information on the woman's affiliation. Yet the male partner's religion plays a role also, in part because the adverse effect of religious intermarriage for the stability of unions has implications for fertility — a point first noted by Becker, Michael, and Landes (1977). The authors observe that if the spouses are mismatched along some important dimension, such as education or religion, they may have reasons to believe that their union is fragile. If so, both partners would have incentives to restrict their investments in spouse-specific human capital — children being the main form — because such investments decline irreversibly in value following the dissolution of the union. This "marital stability effect" is one pathway of causality linking the religious affiliation of both partners to fertility. It predicts that marrying outside one's religion depresses fertility.

There is a second pathway: If the spouses belong to different faiths, they may face conflicting incentives with regard to fertility. This "bargaining effect," which refers to 
how the spouses negotiate these differences, may operate in the same direction as the "marital stability effect," or it may exert a countervailing influence, depending on the specific pair of religions involved. For example, if a Catholic woman marries someone affiliated to the Mormon faith (which has a more pronounced pronatalist theology), the bargaining effect suggests that her fertility will be higher than if she had married within her faith. The opposite would hold if she were to choose a partner who has no religious affiliation (and hence no pronatalist ideologies).

Evidence based on data from the 1987-88 NSFH suggests that both the marital stability and bargaining effects play a role (Lehrer 1996a, 1996b). For example, for a couple with typical characteristics for all other variables, the predicted completed family size is 3.3 if both spouses are Mormon, compared to $2.4-2.5$ if only the wife is Mormon. In this case, both the marital stability and bargaining effects imply that outmarriage has a negative impact on fertility. In contrast, when Protestant women outmarry, there is no discernible influence on family size. In this case, although the intermarriage effect predicts, as always, that marrying outside the faith should depress fertility, the bargaining effect would exert an opposing force if the male partner is affiliated to the Catholic or Mormon Church. This discussion underscores the need to pay attention to the male partner's religion in future studies of fertility.

\section{Women's Work in the Labor Market and at Home}

The Mormon and conservative Protestant faiths make a sharp distinction between male and female roles, encouraging the traditional division of labor within the household when young children are present. Consistent with the view that such religions provide 
institutionalized moral support and psychic rewards to mothers who stay home with their young children, previous research documents a lower level of female employment among members of these faiths when young children are present (Heaton and Cornwall 1989; Chadwick and Garrett 1995; Lehrer 1995, 1999a). Along similar lines, Sherkat (2000) finds that young women who believe that the Bible is the inerrant word of God are more likely than their non-fundamentalist counterparts to be housewives early in the life course. At the other end of the spectrum, although Jewish women are known to be very responsive in their labor supply to the presence of young children (B. Chiswick 1986), their overall commitment to labor market activities is stronger than that of women of other affiliations (Hartman and Hartman 1996).

Early studies found that Catholics emphasized the distinction between appropriate male and female roles (Meir 1972; McMurry 1978). More recent analyses, however, suggest that Catholics have become more egalitarian (Brinkerhoff and MacKie 1984), and indeed somewhat less traditional in this regard than either group of Protestants (Brinkerhoff and MacKie 1985). The direction of this change mirrors transformations that have taken place in the behavior of Catholics in issues related to childrearing (Alwin 1984). Consistent with these changes, the patterns of employment for Catholic women today do not differ significantly from those of their mainline Protestant counterparts (Lehrer 1995).

As noted earlier, there are differences in fertility across religious groups stemming, in part, from religious teachings. Such differences may be expected to have implications for female time allocation patterns, and viceversa (Lehrer and Nerlove 1986). 
As is the case for marital fertility, decisions regarding the allocation of married women's time are influenced not only by the wife's affiliation, but also by that of the husband. To the extent that women in inter-faith unions anticipate a higher probability of marital dissolution, they have incentives to invest more in skills that are specific to the labor-market, as insurance against the possibility of a divorce. In addition, if the spouses are affiliated to different religions, they may face a different structure of perceived costs and benefits associated with female employment, and may therefore need to resolve the resulting conflicts. Thus the "marital stability" and "bargaining" effects that apply to fertility also play a role in the area of women's employment.

Analyses of data on married women with young children from the 1987-88 NSFH confirm the importance of these effects (Lehrer 1995). For example, for women with typical characteristics for all other variables, the predicted probability of nonemployment is 0.55 in the case of a homogamous conservative Protestant union, compared to 0.35 fully twenty percentage points less - if only the wife is conservative Protestant. This pronounced difference reflects the fact that the bargaining effect reinforces the marital stability effect in this instance, and both lead the woman to work more in the labor market in the case of outmarriage. In contrast, the bargaining effect may work in the opposite direction in the case of Catholics (e.g., if a Catholic woman marries a conservative Protestant), and the probability of nonemployment for Catholic women in homogamous unions is the same as that of their counterparts in inter-faith marriages $(0.36)$. 
Recent research emphasizes the importance of gender role traditionalism and homogamy in the labor supply decisions of women of Arab origin in the United States (Read 2004).

Ellison and Bartkowski (2002) examine the effects of religion on another aspect of time allocation, namely, the division of household work between husband and wife. Bivariate analyses reveal that homogamous conservative Protestant households are different from other homogamous households: in the former, the gender segregation of household tasks is greater, and women spend about 4.5 hours more per week performing female typed household work; the gap in the overall hours of household work is nearly identical. Couples in which only one partner is evangelical also display more traditional patterns than their homogamous non-evangelical counterparts. The differences narrow somewhat but remain significant in regressions that include measures of the wife's education and of both partners' labor market activities.

\section{Education, Wages, and Wealth}

Research on the linkage between religious affiliation and educational attainment among non-Hispanic whites reveals that the mean years of schooling is highest for Jews (16.9 for males, 15.8 for females); lowest for conservative Protestants $(13.3,12.9)$, with Catholics $(14.3,13.7)$ and mainline Protestants $(14.5,14.0)$ at the center of the distribution (Lehrer 1999b; see also Darnell and Sherkat 1997; Sherkat and Darnell 1999; B. Chiswick 1988; 1993; Lehrer 2004c).

Applying a model of the supply and demand for funds for investments in schooling developed by Becker and Chiswick (1966) and Becker (1967), these 
differentials have been interpreted within a human capital framework: religious affiliation is viewed as reflecting distinctive features of the home environment that affect both the returns and costs of additional investments in education (B. Chiswick 1988; Lehrer 1999b). On the demand side, religious affiliation can affect the returns from investments in education: among religious groups characterized by larger benefits from schooling, the incentives to pursue education are stronger and thus a higher level of attainment is expected, ceteris paribus. On the supply side, religious affiliation can affect the parents' willingness and ability to supply funds for investments in schooling: a higher level of education is expected for religious groups in which the parents have a greater willingness and ability to supply funds for such investments, ceteris paribus.

More specifically, in this model, described in Figure 1, the demand curve shows the marginal rate of return derived from each additional dollar spent on education. The slope is negative in part because of diminishing marginal returns to additional schooling. The supply curve shows the marginal rate of interest on funds borrowed (or not lent) to finance investments in education. Its upward slope reflects the assumption that obtaining additional funds is increasingly expensive as more human capital investments are undertaken. The usefulness of this model resides in that it yields predictions not only about the level of educational attainment, but also about the rate of return obtained from investments in schooling. The model thus makes it possible to ascertain the relative importance of demand and supply forces in causing unusually high or low schooling levels for various groups.

For the case of Jews, B. Chiswick (1988) presents arguments suggesting that both curves are further to the right than for other groups. On the supply side, the "diaspora 
hypothesis" posits that historically, Jews have placed a high priority on making investments in the human capital of their children, as these are more portable than investments in physical capital (Brenner and Kiefer 1981). ${ }^{2}$ This implies a willingness to invest more in human capital at any given interest rate, i.e., a supply curve that is further to the right.

On the demand side, B. Chiswick (1988) notes that among Jews, family size tends to be small, and large amounts of resources, especially maternal time, are invested on each child during the early, formative years. These investments increase the productivity of formal education and lead to a demand curve that is further to the right. In addition, recent research has noted that Judaism, with its emphasis on the reading and analysis of Hebrew religious texts, is a human capital intensive religion, characterized by a high level of complementarity between religious and secular human capital (C. Chiswick 1999). These characteristics of the religion also imply a demand curve that is further to the right.

Empirically, B. Chiswick (1988) finds that Jews not only have a high level of schooling but also earn a high rate of return on their investments, a result confirmed in subsequent research (Lehrer 1999b). These findings imply that the high educational attainment of Jews is primarily due to the demand side forces outlined above.

With regard to conservative Protestants, there are reasons to believe that the level of schooling is low for both supply and demand reasons. As Sherkat and Darnell (1999, p. 24) observe, "the humanistic values openly taught or implied in secular curricula are frequently in conflict with conservative Protestants' conceptions of authority and submission - particularly the authority of the Bible as the inerrant word of God, and the 
need for children to submit to the will of their parents." Parents' reservations about the learning that takes place in secular institutions are particularly pronounced at the college level; at the same time, the opportunities to attend religious institutions of higher learning are limited and expensive. These concerns about possible negative effects of secular schooling imply that for conservative Protestants, the supply curve is further to the left, because at any given interest rate, parents would be willing to invest less in the education of their children.

On the demand side, a fundamentalist upbringing may imply lower levels of certain types of home investments in child quality that increase the productivity of formal schooling, in part because it is associated with an authoritarian approach to knowledge and a rejection of critical inquiry and unconventional modes of thinking (Sherkat and Darnell 1999). In addition, Darnell and Sherkat (1997) note that conservative Protestant parents often discourage their children from taking college preparatory courses, out of a concern that such courses may be harmful to them. As a result, youths raised in conservative Protestant homes often acquire less human capital in their formative years and may thus be less able to benefit from college; hence their demand curve is further to the left.

Empirical analyses based on data from the 1987-88 NSFH show that the relatively low schooling level of conservative Protestants is accompanied by a rate of return that does not differ significantly from that of mainline Protestants, suggesting that in practice both the demand and supply side forces described above play important roles (Lehrer 1999b). 
Regarding the unaffiliated, evidence is beginning to accumulate that they attain relatively low levels of schooling (Keysar and Kosmin 1995; Glass 1999; Lehrer 2004c). Less is known about the educational achievement of Mormons; the studies to date report conflicting findings (Albrecht and Heaton 1984; Keysar and Kosmin 1995; Lehrer 2004c).

Given that educational attainment is a key determinant of subsequent performance in the labor market, differences by religious affiliation in years of schooling should lead to corresponding differences in wages. The wages of Jews are indeed substantially higher than those of people affiliated with other faiths (B. Chiswick 1993; Lehrer 2004c). In addition to their high level of education, access to schooling institutions of higher quality and a faith that emphasizes this-worldly pursuits (as opposed to the afterlife) are contributing factors.

The wages of conservative Protestant women have been found to be lower than those of their mainline Protestant counterparts by a small margin (Lehrer 2004c). This result has been interpreted as due in part to the relatively low level of schooling and labor market experience for this group. In addition, as noted above, there is greater asymmetry in the intra-household division of labor in conservative Protestant families, with wives spending more time on household work. To the extent that a heavier responsibility for work in the home decreases the level of energy left for market work, the result may be lower productivity on the job and lower wages (Becker 1985). There is also some evidence that the wages of Mormon and unaffiliated women are lower than those of mainline Protestant women by a small margin (Lehrer 2004c). 
Another measure of economic well-being is wealth. Keister (2003) finds that the patterns of differences by religion in wealth closely mirror the differentials by education and wages described above: Jews have the highest level of wealth; conservative Protestants are at the other end of the spectrum, with mainline Protestants and Catholics at the center of the distribution. In explaining the unusually high levels of wealth among Jews, the author notes that in addition to their high educational attainment, their low fertility contributes to wealth accumulation across the generations. The intergenerational transmission of skills conducive to financial success also plays a role, as does the strong emphasis placed by the Jewish theology on worldly pursuits. Keister (2003) suggests that a set of circumstances that is just the opposite explains in part the relatively low levels of wealth among conservative Protestants.

The Timing of Entry into First Union and the Choice of Whether to Cohabit Religious affiliation has an impact on decisions related to entry into first union (whether it is a formal marriage or cohabitation; the timing of the union) largely because of its effects on the various outcomes reviewed above. Women brought up as conservative Protestants and as Mormons have incentives to marry early, because their faith encourages an orientation to home activities, and also very high fertility in the case of Mormons. The relatively low schooling level of conservative Protestants is another factor operating in the same direction. At the other extreme, Jewish women have incentives to delay entry into marriage for several interrelated reasons: their high educational attainment, their low desired level of fertility, and their strong commitment to the labor market. 
Empirically, studies of unions formed prior to the mid 1980s find that religious differentials in this area are pronounced (Thornton et al. 1992; Sander 1993; Lehrer 2000). Analyses of the post-baby boom generation, based on data from the 1995 National Survey of Family Growth (NSFG), show that such differences continue to be large: for women with typical characteristics, the probability of early marriage (by age 20) is 0.02 for Jews, compared to 0.17 for conservative Protestants and Mormons, a difference of fully 15 percentage points. Mainline Protestants and the unaffiliated are at the center of the distribution, with a probability of $0.08-0.09$ (Lehrer 2004a). The more recent analyses also show that although the behavior of Catholics has converged to the mainline Protestant pattern in most domains of family life, their behavior has remained distinctive in the area of entry into marriage: their probability of having entered first marriage by age 20 is only 0.05 . It appears that the Catholic proscription against divorce continues to have some effect, encouraging Catholic individuals to search longer and more carefully in the marriage market.

Cohabitation has been found to be least likely for Mormons and most likely for individuals without a religious affiliation (Lehrer 2000, 2004a). Analyses of data from the 1995 NSFG show that for women with typical characteristics, the probability of having cohabited by age 20 is 0.12 for Mormons; for the unaffiliated, the probability is twice that amount (Lehrer 2004a). The low prevalence of cohabitation among Mormons is due in part to their conservative attitudes toward premarital sex, which imply high subjective costs associated with entering informal living arrangements (Sweet and Bumpass 1990). With their high fertility rate, Mormon women also have an incentive to avoid the more fragile cohabitation arrangements, given that stable two-parent households are the 
optimal institutional arrangement for the raising of children (Weiss and Willis 1985; Willis and Haaga 1996). Furthermore, marriage provides greater economic security (Grossbard-Shechtman 1993), and this makes it especially attractive to Mormon women, who tend to orient their investments to home production when their children are young. At the other extreme, the unusually high levels of cohabitation among the unaffiliated reflect the fact that the subjective costs of sharing living arrangements without a legal contract are low for this group.

Countervailing influences are present for Jews and conservative Protestants. In the case of Jews, their liberal attitudes toward premarital sex, low fertility, and high levels of female education and employment, all combine to predict a high prevalence of informal unions. However, the elevated earnings of Jewish men point in the opposite direction, since better economic prospects of the male partner imply stronger incentives to choose the arrangement that involves more commitment, i.e., marriage (Willis and Michael 1994). For the opposite reasons, the net impact is also ambiguous for conservative Protestants.

Empirically, there is conflicting evidence for Jews. While some studies find that they stand out for their high rate of cohabitation (Lehrer 2000, Willis and Michael 1994), no significant effect could be discerned in an analysis of a more recent data set (Lehrer 2004a). For conservative Protestants, the effects described above appear to cancel out, as their prevalence of cohabitation is not significantly different from that of mainline Protestants (Lehrer 2000, 2004a).

Given that the behavior of Catholics has converged to the mainline Protestant pattern in most dimensions of family life, it is not surprising that they do not differ much 
from mainline Protestants in the area of cohabitation. One study (Lehrer 2004a) finds a small difference, with Catholics somewhat less likely to have cohabited by age 20 (a probability of 0.16 , as opposed to 0.20 ); another finds no difference (Lehrer 2000).

\section{The "No Religion" Category and the Role of Religiosity}

Most research to date on the effects of religious affiliation has paid little or no attention to the role of religiosity, in part because the data sets employed have often lacked adequate measures of this dimension of religion. For example, the numerous studies reviewed above that used the 1987-88 NSFH were hampered by the fact that the survey only included a measure of religiosity as of the interview date, a variable that is unfortunately endogenous to most outcomes of interest.

A main theme running through this paper is that religious affiliation influences economic and demographic behavior because it has an impact on the perceived costs and benefits of various decisions made by individuals and families over the life cycle. The effects should therefore be stronger for those individuals who participate more frequently in religious observances and adhere more closely to the teachings of their faith. For example, the likelihood that a Mormon woman will choose to avoid informal cohabiting arrangements should be more pronounced if she is more religious. Studies that focus on religious affiliation and include analyses of the effects of religiosity generally make this argument either implicitly or explicitly (e.g., Read 2004; Lehrer 2004a).

Recently, however, it has become clear that the religiosity effects are in fact more complex because, as a growing body of literature shows, participation in religious activities per se is associated with benefits in a wide range of areas (Smith 2003; Waite 
and Lehrer 2003). In particular, religious participation among youths has been linked to a lower probability of substance abuse and juvenile delinquency (Donahue and Benson 1995); a lower incidence of depression among some groups (Harker 2001); delayed sexual debut (Bearman and Bruckner 2001) and entry into cohabitation (Lehrer 2004a); more positive attitudes toward marriage and having children, and more negative attitudes toward unmarried sex and premarital childbearing (Marchena and Waite 2001). ${ }^{3}$

The discussion above suggests that religiosity can have an impact on economic and demographic variables through two distinct channels. A higher level of religiosity may (a) accentuate the effects associated with religious affiliation, and (b) lead to better outcomes because of its generally salutary effects on well-being and health. A recent study illustrates how these two channels may exert countervailing forces (Lehrer 2004b). As noted above, conservative Protestants have a lower level of educational attainment than their mainline Protestant counterparts, because various aspects of the conservative Protestant theology tend to discourage investments in secular education. Using the standard argument that religiosity should make the effects of affiliation more pronounced, one would predict that among conservative Protestants, those who are most religious should be at the greatest educational disadvantage.

In fact, there is evidence suggesting that the opposite is the case (Lehrer 2004b). Analyses based on data from the 1995 NSFG show that among young women raised as conservative Protestants, those who attended church once a month or more often during adolescence attain more schooling than their counterparts brought up in less observant homes. The zero-order effect is a difference of one year of schooling; the gap narrows to eight-tenths of a year when background factors are controlled. This result underscores the 
positive effects of religious involvement for children in the area of educational attainment: children who grow up in homes where there is some religious involvement have higher levels of social capital and mental well-being, and are better able to benefit from investments in education; in the language of the human capital model presented earlier, they have a demand curve that is further to the right. ${ }^{4}$ This finding also illustrates clearly that one should no longer continue to assume that a higher level of religiosity merely accentuates any differences across religious groups.

At the same time that the literature on the effects of religious affiliation on economic and demographic outcomes has paid too little attention to the role of religiosity, the converse has also been true. For example, the large number of studies on the effects of religiosity on the quality and stability of marital unions largely ignores religious affiliation (e.g., Glenn and Supancic 1984; Booth et al. 1995; Call and Heaton 1997). In all of this research, intra- and inter-faith couples are lumped together, without considering that while a high level of religiosity on the part of both partners may be a positive factor for homogamous marriages, it is most likely a negative factor among heterogamous marriages. If both partners are strongly committed to their own, distinct faiths, this should be worse, from the perspective of marital quality and stability, than if neither really practices their religion (Waite and Lehrer 2003). The results from the studies to date in this area thus reflect a mixture of positive and negative effects and have no clear interpretation.

Yet another reason for seeking more integration between these two dimensions of religion in future research is that levels of religiosity are not uniform across the various groups. For example, conservative Protestants tend to participate in church services more 
frequently than members of most other religious groups. Thus if differences in religious involvement are not considered in the analyses, some of the estimated "conservative Protestant" effect may actually be a religiosity effect.

Individuals who report "no religion" constitute a relatively small and heterogeneous group: it includes atheists, agnostics, and persons who were raised without an affiliation due to other circumstances (e.g., being a child from an inter-faith marriage). For this reason, many studies on the effects of religious affiliation on economic and demographic outcomes have omitted this group. The growing body of literature on the effects of religiosity helps interpret results from those studies that have included it. As Glenn (1987) has noted, it is useful to think of the "no religion" category as one extreme in the religiosity scale. Thus the benefits that are typically associated with religious involvement are not available to the unaffiliated. This perspective provides a consistent interpretation for the findings about this group reviewed earlier, namely, that those with no religious affiliation tend to display lower levels of educational attainment and wages, and that rates of divorce are high among couples in which one or both partners are unaffiliated.

\section{Concluding Remarks}

This paper has underscored the fruitfulness of thinking about religious affiliation in terms of how it influences the costs and benefits of various interrelated decisions made over the life cycle by individuals and families; it has also shown that the complementarity of religion within the context of marriage makes it essential to consider the affiliations of both spouses for behaviors that pertain to couples. In addition, it has demonstrated that in 
interpreting the effects of religion, seeing the entire economic and demographic picture contributes significantly to a good understanding of any given piece.

Recent research has added to our knowledge of the conditions under which religion tends to exert the strongest effects on fertility (McQuillan 2004). As the author observes (pp. 46-47):

...religious values, while important, are likely to play a critical role in shaping demographic behavior only when religious authorities have at their disposal a menu of rewards and sanctions that will encourage the faithful to conform. This, in turn, is most apt to come about when churches are able to build a network of religious institutions that play a formative role in the lives of members and to exercise influence over civil institutions in society as well.

It seems likely that such conditions are relevant not only to fertility, which is the focus of McQuillan's analysis, but also to other demographic and economic outcomes. Further research in this direction is likely to expand our understanding of the pathways through which affiliation with various religious groups gives rise to differences in costs and benefits, and the circumstances under which such differences are most important.

Future studies should build on what we have learned in the process of integrating our knowledge of the effects of religious affiliation with the large and growing body of research on the generally beneficial influences of some religious involvement, whatever the faith may be. Future research should also pay more attention to the distinct patterns for minorities including African-Americans, Hispanics, and Asian-Americans, as most studies to date have focused only on non-Hispanic whites. Efforts in this direction have begun (e.g., Wilcox and Wolfinger 2003; Read 2004). Finally, this paper has focused on results for the United States. An important avenue for future research is to compare the 
empirical regularities described here with the patterns that prevail elsewhere, in other industrialized nations and in less developed economies. 


\section{ENDNOTES}

1 As discussed later in the text, the behavior of Catholics has also converged to the mainline Protestant pattern in many other areas. For a discussion of the role of the Second Vatican Council and Pope VI's Encyclical Humanae Vitae in these transformations, see D’Antonio and Cavanaugh (1983) and Dolan (1985).

2 See Ayal and Chiswick (1983) for additional discussion of this hypothesis. The authors emphasize that only some investments in human capital are highly transferable, being equally productive in all locations. Others (such as an education in law) are not portable.

3 Under certain circumstances, the effects of religious involvement can be adverse; see Waite and Lehrer (2003).

$4 \quad$ Earlier research finds beneficial effects of religious participation on other educational outcomes, including school attendance (Freeman 1986); test scores and educational expectations (Regnerus 2000); and time spent on homework, advanced mathematics credits earned, and the probability of earning a high school diploma, among other measures (Muller and Ellison 2001). 


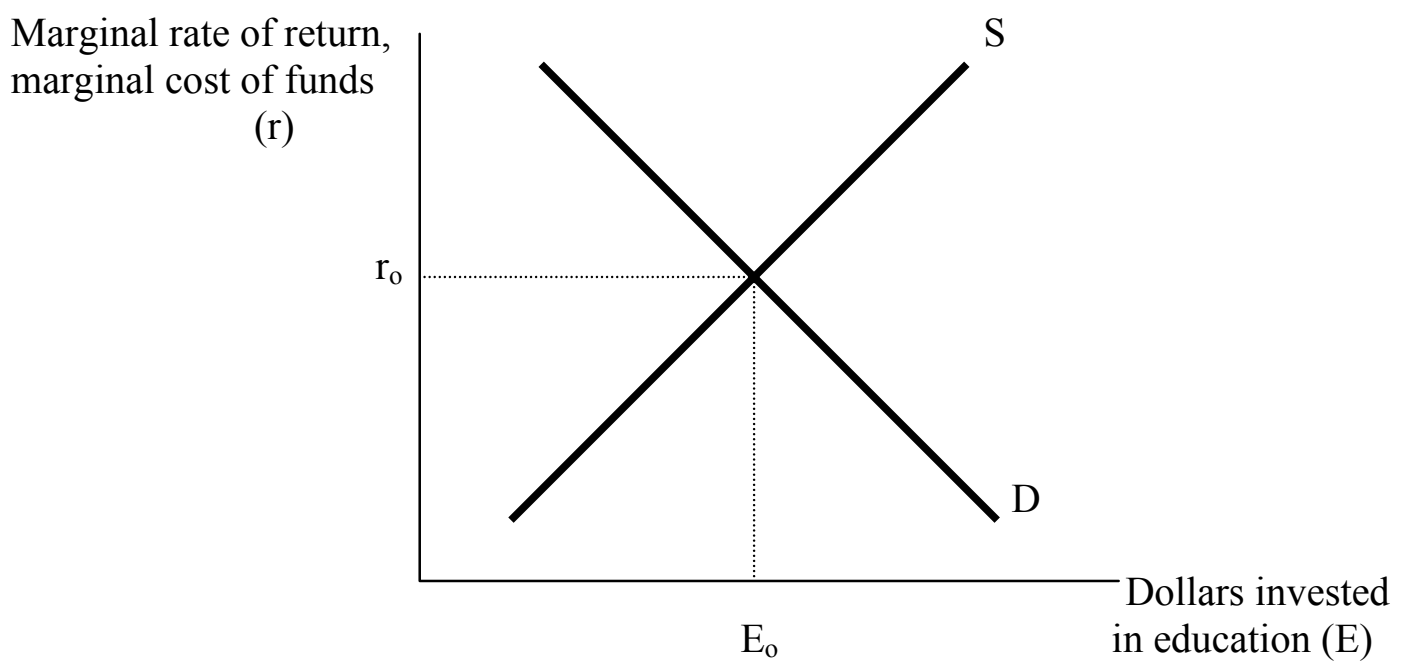

Figure 1. The demand and supply of funds for investments in schooling. The optimal level of investment in schooling is $E_{0}$. At this point, the marginal interest cost of funds is equal to the marginal rate of return $\left(r_{o}\right)$. 


\section{REFERENCES}

Albrecht, Stan L. and Tim B. Heaton. 1984. "Secularization, Higher Education, and Religiosity." Review of Religious Research 26(1): 43-58.

Alwin, Duane F. 1984. "Trends in Parental Socialization Values: Detroit, 19581983." American Journal of Sociology 90(2): 359-382.

Ayal, Eliezer B. and Barry R. Chiswick. 1983. "The Economics of the Diaspora Revisited." Economic Development and Cultural Change 31(4): 861-875.

Bearman, Peter S. and Hannah Bruckner. 2001. "Promising the Future: Virginity Pledges and First Intercourse." American Journal of Sociology 106(4): 859-912.

Becker, Gary S. 1967. Human Capital and the Personal Distribution of Income. Wotynsky Lecture No. 1, Ann Arbor, Michigan: University of Michigan Press.

- - - 1973. “A Theory of Marriage.” Pp. 299-344 in Theodore W. Schultz (ed.) Economics of the Family: Marriage, Children, and Human Capital." Chicago: The University of Chicago Press.

- - - 1981. A Treatise on the Family. Cambridge: Harvard University Press.

- - - 1985. "Human Capital, Effort, and the Sexual Division of Labor." Journal of Labor Economics 3(1): S33-58.

Becker, Gary S. and Barry R. Chiswick. 1966. "Education and the Distribution of Earnings.” American Economic Review 56 (May): 358-369.

Becker, Gary, Elizabeth M. Landes, and Robert T. Michael. 1977. "An Economic Analysis of Marital Instability.” Journal of Political Economy 85(6): 1141-87.

Booth, Alan, David R. Johnson, Ann Branaman, and Alan Sica. 1995. "Belief and Behavior: Does Religion Matter in Today's Marriage?" Journal of Marriage and the Family 57(3): 661-671.

Brenner, Reuven and Nicholas M. Kiefer. 1981."The Economics of the Diaspora: Discrimination and Occupational Structure." Economic Development and Cultural Change (April): 517- 533. 
Brinkerhoff, Merlin B. and Marlene M. MacKie. 1984. "Religious

Denominations' Impact upon Gender Attitudes: Some Methodological Implications." Review of Religious Research 25(4): 365-378.

-----1985. "Religion and Gender: A Comparison of Canadian and American

Student Attitudes." Journal of Marriage and the Family (May): 415 - 429.

Bumpass, Larry L. and James A. Sweet. 1972. "Differentials in Marital Stability: 1970.” American Sociological Review 37(6): 754-766.

Call, Vaughn R. and Tim B. Heaton. 1997. "Religious Influence on Marital Stability." Journal for the Scientific Study of Religion 36(3): 382- 392.

Chadwick, Bruce A. and H. Dean Garrett. 1995. "Women's Religiosity and Employment: the LDS Experience." Review of Religious Research 36(3): 277-293.

Chiwick, Barry. 1986. "Labor Supply and Investments in Child Quality: A Study of Jewish and Non-Jewish Women." Review of Economics and Statistics 68(4): 700-703.

- - - 1988. "Differences in Education and Earnings Across Racial and Ethnic Groups: Tastes, Discrimination, and Investments in Child Quality." Quarterly Journal of Economics 103 (3): 571-597

- - - 1993. "The Skills and Economic Status of American Jewry: Trends over the Last Half-Century." Journal of Labor Economics 11(1): 229-242.

Chiswick, Carmel. 1997. "Determinants of Religious Intermarriage: Are Jews Really Different?" Pp. 247-257 in Sergio DellaPergola and Judith Even (eds.) Papers in Jewish Demography, 1993, in Memory of U.O.Schmelz. Jerusalem: World Union of Jewish Studies.

- - - 1999. "An Economic Model of Jewish Continuity." Contemporary Jewry 20: $30-56$.

Chiswick, Carmel and Evelyn L. Lehrer. 1991. "Religious Intermarriage: An Economic Perspective." Contemporary Jewry 12: 21-34.

D'Antonio, William V. and Mark J. Cavanaugh. 1983. "Roman Catholicism and the Family." Pp. 141-162 in William V. D'Antonio and Joan Aldous (eds.) Families and Religions: Conflict and Change in Modern Society. Beverly Hills: Sage Piblications.

Darnell, Alfred and Darren E. Sherkat. 1997. "The Impact of Protestant Fundamentalism on Educational Attainment." American Sociological Review 62 (April): 306-315. 
Della Pergolla, Sergio. 1980. “atterns of American Jewish Fertility.” Demography 17(3): 261-273.

Dolan, Jay P. 1985. The American Catholic Experience: A History from Colonial Times to the Present. Garden City, New York: Doubleday \& Company, Inc.

Donahue, Michael J. and Peter L. Benson. 1995. "Religion and the Well-Being of Adolescents." Journal of Social Issues 51(2): 145-160

Ellison, Christopher G. and John P. Bartkowski. 2002. "Conservative Protestantism and the Division of Household Labor Among Married Couples." Journal of Family Issues 23(8): 950-985.

Freeman, Richard B. 1986. "Who Escapes? The Relationship of Churchgoing and Other Background Factors to the Socioeconomic Performance of Black Male Youths from Inner-City Tracts.” Pp. 353- 376 in Richard B. Freeman and Harry J. Holzer (eds.) The Black Youth Employment Crisis. Chicago: The University of Chicago Press.

Glass, Jennifer. 1999. “Growing Up Fundamentalist: Effects on Women's Early Life Course Transitions and Adult Attainment." Presented at the annual meetings of the Population Association of America, New York City.

Glenn, Norval D. 1987. “The Trend in 'No Religion' Respondents to U.S. National Surveys, Late 1950s to Early 1980s." The Public Opinion Quarterly 51(3): 293314.

Glenn, Norval D. and Michael Supancic. 1984. "The Social and Demographic Correlates of Divorce and Separation in the United States: An Update and Reconsideration." Journal of Marriage and the Family (August): 563-575.

Goldscheider, Calvin. 1971. Population, Modernization, and Social Structure. Boston: Little, Brown and Company.

Goldscheider, Calvin and William D. Mosher. 1991. "Patterns of Contraceptive Use in the United States: The Importance of Religious Factors." Studies in Family Planning 22(2): 102-115.

Grossbard-Shechtman, Shoshana. 1993. On the Economics of Marriage: A Theory of Marriage, Labor, and Divorce. Boulder: Westview Press.

Harker, Kathryn. 2001. "Immigrant Generation, Assimilation, and Adolescent Psychological Well-Being.” Social Forces 79(3): 969-1004. 
Hartman, Moshe and Harriet Hartman. 1996. Gender Equality and American Jews. Albany, New York: State University of New York Press.

Heaton, Tim B. 1986. "How does Religion Influence Fertility? The Case of Mormons." Journal for the Scientific Study of Religion 25(2): 248- 258.

Heaton, Tim B. and Marie Cornwall. 1989. "Religious Group Variation in the Socioeconomic Status and Family Behavior of Women." Journal for the Scientific Study of Religion 28(3): 283-299.

Hurst, Dawn S. and Frank L. Mott. 2003. “Jewish Fertility and Population Sustenance: Contemporary Issues and Evidence.” Unpublished manuscript, Ohio State University.

Iannacconne, Larry. 1994. "Why Strict Churches are Strong." American Journal of Sociology 99(5):1180-1211.

Jones, E.F. and C.F. Westoff. 1979. "The End of 'Catholic' Fertility.” Demography 16(2): 209-218.

Keister, Lisa A. 2003. "Religion and Wealth: The Role of Religious Affiliation and Participation in Early Adult Asset Accumulation." Social Forces 82: 173- 205.

Keysar, Ariela and Barry Kosmin. 1995. "The Impact of Religious Identification on Differences in Educational Attainment among American Women in 1990." Journal for the Scientific Study of Religion 34(1): 49-62.

Lehrer, Evelyn L. 2004a. "The Role of Religion in Union Formation: An Economic Perspective." Population Research and Policy Review 23: 161-185.

- - - 2004b. "Religiosity as a Determinant of Educational Attainment: The Case of Conservative Protestant Women in the United States." Review of Economics of the Household 2(2): 203-219.

- - - 2004c. "Religious Affiliation and Participation as Determinants of Women's Educational Attainment and Wages." Forthcoming in Christopher Ellison and Robert Hummer (eds.) Religion, Family Life, and Health in the United States.

- - - 2000. "Religion as a Determinant of Entry into Cohabitation and Marriage." Pp. 227-252 in Linda Waite, Christine Bachrach, Michelle Hindin, Elizabeth Thomson, and Arland Thornton (eds.) The Ties that Bind: Perspectives on Marriage and Cohabitation. Hawthorne: Aldine de Gruyter.

- - - 1999a. "Married Women's Labor Supply Behavior in the 1990s: Differences by Life-Cycle Stage.” Social Science Quarterly 80(3): 574-590. 
- - - 1999b. "Religion as a Determinant of Educational Attainment: An Economic Perspective.” Social Science Research 28: 358-379.

- - - 1998. "Religious Intermarriage in the United States: Determinants and Trends." Social Science Research 27: 245-263.

- - - 1996a. "Religion as a Determinant of Fertility." Journal of Population Economics 9: 173-196.

- - - 1996b. "The Role of the Husband's Religion on the Economic and Demographic Behavior of Families." Journal for the Scientific Study of Religion 35(2): 145155.

- - - 1996c. "The Determinants of Marital Stability: A Comparative Analysis of First and Higher Order Marriages." Pp. 91-121 in Research in Population Economics 8, edited by T. Paul Schultz. Greenwich: JAI Press.

- - - 1995. "The Effects of Religion on the Labor Supply of Married Women." Social Science Research 24: 281-301.

Lehrer, Evelyn L. and Carmel U. Chiswick. 1993. "Religion as a Determinant of Marital Stability." Demography 30(3): 385-404.

Lehrer, Evelyn L. and Marc Nerlove. 1986. "Female Labor Force Behavior and Fertility in the United States." Annual Review of Sociology 12: 181-204.

Marchena, Elaine and Linda J. Waite. 2001. "Marriage and Childbearing Attitudes in Late Adolescence: Gender, Race and Ethnic Differences." Revised version of paper presented at the meetings of the Population Association of America, March 2000, Los Angeles.

Marcum, John P. 1981. "Explaining Fertility Differentials among U.S. Protestants." Social Forces 60(2): 532-543.

McMurry, Martha. 1978. "Religion and Women's Sex Role Traditionalism." Sociological Focus 11(2): 81-95.

McQuillan, Kevin. 2004. "When Does Religion Influence Fertility?” Population and Development Review 30(1): 25-56.

Meier, Harold C. 1972. "Mother-Centeredness and College Youths' Attitudes toward Social Equality for Women: Some Empirical Findings." Journal of Marriage and the Family 34 (February): 115-121.

Michael, Robert. 1979. "Determinants of Divorce.” Pp. 223-268 in L. Levy-Garboua (ed.) Sociological Economics. Beverly Hills: Sage. 
Mosher, William D. and Gerry E. Hendershot. 1984. "Religion and Fertility: A Replication." Demography 21(2): 185-192.

Mosher, William D., David P. Johnson, and Marjorie C. Horn. 1986. "Religion and Fertility in the United States: The Importance of Marriage Patterns and Hispanic Origin." Demography 23(3): 367-380.

Muller, Chandra and Christopher G. Ellison. 2001. "Religious Involvement, Social Capital, and Adolescents' Academic Progress: Evidence from the National Education Longitudinal Study of 1988." Sociological Focus 34(2): 155-183.

Read, Jen'nan G. 2004. Culture, Class, and Work among Arab-American Women. New York: LFB Scholarly Publishing LLC.

Regnerus, Mark D. 2000. "Shaping Schooling Success: Religious Socialization and Educational Outcomes in Metropolitan Public Schools." Journal for the Scientific Study of Religion 39: 363-370.

Sander, William. 1993. "Catholicism and Marriage in the United States." Demography 30(3): 373-384.

- - - - 1995. The Catholic Family: Marriage, Children, and Human Capital. Boulder: Westview Press.

Sherkat, Darren E. 2000. "That They be Keepers of the Home: The Effect of Conservative Religion on Early and Late Transition into Housewifery." Review of Religious Research 41(3): 344-358.

- - - 2004. "Religious Intermarriage in the United States: Trends, Patterns, and Predictors." Social Science Research 33: 606-625.

Sherkat, Darren E. and Alfred Darnell. 1999. "The Effects of Parents' Fundamentalism on Children's Educational Attainment: Examining Differences by Gender and Children's Fundamentalism." Journal for the Scientific Study of Religion 38(1): 23-35.

Smith, Christian. 2003. "Theorizing Religious Effects Among American Adolescents." Journal for the Scientific Study of Religion 42(1): 17-30.

Stark, Rodney and Roger Finke. 2000. Acts of Faith: Explaining the Human Side of Religion. Berkeley: University of California Press.

Sweet, James A. and Larry L. Bumpass. 1990. "Religious Differentials in Marriage Behavior and Attitudes.” NSFH Working Paper No. 15, University of Wisconsin. 
Thornton, Arland. 1979. "Religion and Fertility: The Case of Mormonism." Journal of Marriage and the Family 41(1): 131-142.

Thornton, Arland, WilliamG. Axinn, and Daniel H. Hill. 1992. "Reciprocal Effects of Religiosity, Cohabitation, and Marriage." American Journal of Sociology 98(3): 628-651.

Waite, Linda and Evelyn L. Lehrer. 2003. "The Benefits from Marriage and Religion in the United States: A Comparative Analysis." Population and Development Review 29(2): 255-275.

Weiss, Yoram and Robert J. Willis. 1985. "Children as Collective Goods." Journal of Labor Economics 3: 268-92.

Wilcox, W. Bradford and Nicholas H. Wolfinger. 2003. "Then Comes Marriage? Religion, Race, and Marriage in Urban America." Presented at the annual meetings of the Population Association of America, Minneapolis.

Willis, Robert J. and John G. Haaga. 1996. "Economic Approaches to Understanding Nonmarital Fertility. Pp. 67-86 in J. B. Casterline, R. D. Lee, and K. A. Foote (eds.) Fertility in the United States: New Patterns, New Theories. New York: The Population Council.

Willis, Robert J. and Robert T. Michael. 1994. "Innovation in Family Formation: Evidence on Cohabitation in the United States." Pp. 9-45 in John Ermisch and Naohiro Ogawa (eds.) The Family, The Market and the State in Ageing Societies. Oxford: Clarendon Press. 